\title{
ASSOCIATION ANALYSIS BETWEEN THE C516T POLYMORPHISM IN THE 5-HT2A RECEPTOR GENE AND SCHIZOPHRENIA
}

\author{
Vivian Bertola, Quirino Cordeiro, Stevin Zung, Elisabete Cristina Miracca, Homero Vallada
}

\begin{abstract}
Data from epidemiological studies have demonstrated that genetics is an important risk factor for schizophrenia. Disturbances of serotonergic brain pathways have been implicated in the pathophysiology of schizophrenia. Some studies have suggested that the efficacy of atypical antipsychotics on schizophrenia treatment may be related to the serotonin $2 \mathrm{~A}$ receptor $(5-\mathrm{HT} 2 \mathrm{~A})$, and that serotonergic drugs may induce psychotic symptoms. Thus, the aim of this study was to investigate the association between the C516T polymorphism and schizophrenia in a Brazilian population composed by 246 patients and 315 healthy matched controls in a case-control approach. No statistically differences were observed in allelic $\left(\chi^{2}=1.77,1\right.$ d.f., $\left.p=0.18\right)$ or genotypic $\left(\chi^{2}=1.69,2\right.$ d.f., $\left.p=0.42\right)$ distributions between cases and controls. The results suggest that the $\mathrm{C} 516 \mathrm{~T}$ polymorphism of the 5 -HT2A receptor gene is not related to the susceptibility for schizophrenia in our Brazilian sample.
\end{abstract}

KEY WORDS: serotonin, genetic association, allele, genotype, 5HT2A, schizophrenia.

\begin{abstract}
Análise de associação entre o polimorfismo C516T do gene do receptor 5-HT2A e esquizofrenia
RESUMO - Estudos epidemiológicos têm demonstrado que o componente genético é importante fator de risco para o desenvolvimento de esquizofrenia. Alterações nas vias cerebrais serotonérgicas têm sido relacionadas à fisiopatologia da esquizofrenia. Algumas investigações têm sugerido que a eficácia de antipsicóticos atípicos no tratamento da esquizofrenia pode estar relacionada com sua ação no receptor de serotonina subtipo 2A (5-HT2A), e que drogas serotonérgicas podem provocar sintomas psicóticos. Assim, o objetivo desta investigação foi examinar a associação entre o polimorfismo C516T do gene do receptor 5HT2A e esquizofrenia em uma amostra brasileira composta por 246 pacientes e 315 controles saudáveis e pareados em um estudo tipo caso-controle. Não foram observadas diferenças na distribuição alélica $\left(\chi^{2}=1,77\right.$, 1 d.f., $p=0,18,1$ d.f.) e genotípica $\left(\chi^{2}=1,69,2\right.$ d.f., $\left.p=0,42\right)$ entre os grupos de pacientes e controles. Os resultados sugerem que o polimorfismo C516T gene do receptor 5-HT2A não é fator de susceptibilidade para esquizofrenia na amostra brasileira estudada.
\end{abstract}

PALAVRAS-CHAVE: serotonina, associação genética, alelo, genótipo, 5HT2A, esquizofrenia.

Schizophrenia (SCZ) is a severe mental disorder characterized by psychotic symptoms (delusions, hallucinations), disturbances of thought, affect, volition and behavior, with late-adolescent or early adult onset and, in most cases, presenting a chronic course. The average lifetime prevalence is about $1 \%$ in general population. Evidence from family, twin and adoption studies has suggested that there is an important participation of a genetic component on the etiology of SCZ1 . However, the mode of inheritance is complex and non-Mendelian, but rather of a polygenic and multifactorial nature. The contribution of single relevant gene must be small, thus association studies involving case-control approaches have been employed to evaluate the allelic variations at specific candidate genes which may be related to the etiopathology of the disorder ${ }^{2}$. Researches with hallucinogens drugs have suggested that serotonin (5hydroxytryptophan: $5-\mathrm{HT}$ ) would be an important neurotransmitter in the pathogenesis of $\mathrm{SCZ}^{3}$. The two major classes of psychotomimetics, the indoleamines and phenethylamines may hold their principal effects through a common action upon serotonin receptors ${ }^{4}$. Evidences that serotonergic-depleting drugs could alleviate some symptoms of SCZ also helped to build the theory that an increase in serotonin activation may be related to the disorder ${ }^{5}$. More evidences of the interest of serotonin in SCZ come from the findings by Arora and Meltzer ${ }^{6}$ that reported a significant decrease in the number of cerebral

Department and Institute of Psychiatry, Progene-LIM23, University of São Paulo Medical School, São Paulo SP, Brazil.

Received 4 July 2006, received in final form 25 September 2006. Accepted 14 November 2006.

Dr. Quirino Cordeiro - Rua Oscar Freire 1758 / 35-B - 05409-011 São Paulo SP - Brasil. E-mail: qcordeiro@yahoo.com 
5-HT receptors in patients with $\mathrm{SCZ}$ as compared to the controls, negating the role of neuroleptics for this difference, and also from the results by Joyce et al. ${ }^{7}$ that showed that serotonin uptake sites and receptors are altered in the limbic system of patients with the disorder.

Fourteen known 5-HT receptors subtypes are involved in serotonin action ${ }^{8}$. Among the $5-\mathrm{HT}$ receptors, the 5 -HT subtype $2 \mathrm{~A}$ receptor $(5-\mathrm{HT} 2 \mathrm{~A})$ is highly expressed in the neocortex, limbic region, and the basal ganglia, and has been focused as one of the major target for atypical antipsychotics, like olanzapine and clozapine, through receptor affinity and binding studies ${ }^{8-10}$. The 5 -HT2A is a G-protein-coupled receptor (GPCR) seven transmembrane domains whose activation leads to the stimulation of the enzyme phospholipase $C$ and to the subsequent hydrolysis of the membrane phosphoinositides, with the synthesis of the second messengers, inositol triphosphate and diacylglycerol ${ }^{11}$. The 5-HT2A gene was mapped by Sparkes et al. ${ }^{12}$ on chromosome 13q14.2, which has been known as a promising chromosomal region could harbor candidate genes for SCZ through some linkage studies ${ }^{13}$. A meta-analysis of wholegenome linkage scans confirmed linkage between SCZ and markers on the long arm of chromosome $13^{14}$. The 5-HT2A gene consists of 3 exons separated by 2 introns and spans over $20 \mathrm{~kb}^{15}$. At least seven single nucleotide polymorphisms (SNPs) are located within the coding region of the human 5-HT2A receptor gene. Five of the seven nucleotide polymorphisms (T25N, I197V, S421F, A447V, and H452Y) result in amino-acid mutations (non-synonymous SNPs). The remaining two of the seven nucleotide polymorphisms (T102C and C516T) do not alter the 5-HT2A receptor amino-acid sequence (synonymous SNPs) $)^{11,16}$.

Thus in the present study, the silent C516T polymorphism (rs6305) which is located in exon 2 of the 5 -HT2A receptor gene will be investigated as a possible risk factor for SCZ.

\section{METHOD}

Sample - All controls, parents and schizophrenic patients provided written informed consent. The ethical approval for the study was obtained from the Ethics Committee at the Hospital das Clínicas, University of São Paulo Medical School (CAPPesq).

A) Patients sample: 246 patients were recruited from inpatient and outpatient services at the Institute of Psychiatry of the Hospital das Clínicas, University of São Paulo Medical School and diagnosed according to DSM-IV ${ }^{17}$ criteria for SCZ. B) Controls sample: 315 age and sex matched healthy controls were recruited from the Blood Donation Service at the Hospital das Clínicas, University of São Paulo Medical School.
Genotyping - We collected ten milli-liters of venous blood from each subject and genomic DNA was extracted from lymphocytes using "salting out" protocol ${ }^{18}$. The sequence containing the $\mathrm{C} 516 \mathrm{~T}$ variant in the $5 \mathrm{HT} 2 \mathrm{~A}$ gene ${ }^{19,20}$ was amplified by PCR using primers (5'GTATGGGTACCGGTGGCCTCT-3' and 5'-GTCCAAACAGCAATGATTTTCA-3') described in Arranz et al. ${ }^{19}$. The amplified products were digested with Sau96I restriction enzyme and the genotype was determined after electrophoresis on ethidium bromide stained $2 \%$ of the agarose gels. The C516 allele showed fragments of 109 and 87 base pairs, whereas the T516 allele remained uncut.

To avoid errors, genotyping was read by two independently trained research technicians. When a disagreement arose the genotyping was repeated. In addiction, random re-genotyping was repeated in $20 \%$ of the sample.

Statistical analysis - The statistical power of the sample was evaluated using the CaTS Program (Center for Statistical Genetics - The University of Michigan) (http://www.sph. umich.edu/csg/abecasis/CaTS/index.html). The Hardy-Weinberg equilibrium test was performed by HWE program ${ }^{21}$. Chi-square test, used to investigate possible association between genotypes, alleles and homozygosity with $S C Z$, was performed by the Epilnfo version 6.0. The significance level for all the statistical tests was 0.05 .

\section{RESULTS}

The power of the sample, based on 246 patients and 315 controls, disorder prevalence of $1 \%$, average allelic frequency around $4 \%$, multiplicative model with the genotype relative risk $=2.0^{22,23}$, and significance level of 0.05 , was $74 \%$.

There were no significant deviations from the Hard-Weinberg equilibrium in any of the sample for the polymorphism studied (patients $p=0.09$ and controls $\mathrm{p}=0.08$ ).

Case-control analysis provided no differences in genotypic $\left(\chi^{2}=1.69, p=0.42,2 d\right.$.f.) and allelic $\left(\chi^{2}=1.77\right.$, $\mathrm{p}=0.18,1$ d.f.) distributions between patients and controls samples (Table). There was no association bet-

Table. Distributions of the C516T alleles and genotypes frequencies in SCZ patients and controls samples.

\begin{tabular}{lcccc}
\hline & SCZ (\%) & Controls (\%) & $\chi^{2}$ & $\mathrm{p}$ Value \\
\hline Alleles & & & 1.77 & 0.18 \\
C & $477(96.9)$ & $601(95.3)$ & & \\
T & $15(3.0)$ & $29(4.6)$ & & \\
Total & $492(100)$ & $630(100)$ & & \\
Genotypes & & & 1.69 & 0.42 \\
CC & $232(94.3)$ & $288(91.4)$ & & \\
CT & $13(4.8)$ & $25(7.9)$ & & \\
TT & $1(0.4)$ & $2(0.6)$ & & \\
Total & $246(100)$ & $315(100)$ & \\
\hline
\end{tabular}


ween homozigosity and SCZ as well $\left(\chi^{2}=1.54, p=\right.$ $0.21,1$ d.f.).

\section{DISCUSSION}

Due the evidences of involvement of the serotonergic system in the pathophisiology of SCZ, many studies have been carried out with polymorphisms of this cerebral pathway and $\mathrm{SCZ}^{24}$. The 5-HT2A polymorphisms have been the most investigated because of its cerebral location, role on atypical antipsychotics action, and interesting chromosomal positional of its gene. Among the 5-HT2A polymorphisms, the T102C has been the most investigated in SCZ, however with inconclusive results according to recent meta-analy$\mathrm{sis}^{9,25}$. Other serotonergic polymorphisms of 5-HT2A have also been studied, like the C516T, not only in SCZ susceptibility. Studies with other psychiatric disorders showed lack of association with bipolar disorder $^{26}$ and association with obsessive-compulsive disorder ${ }^{27}$.

In the present investigation we tested the association of the C516T polymorphism of 5-HT2A and SCZ. However, the results did not support the hypothesis that this polymorphism has a main role in the development of SCZ in our sample. We have found no evidence for allelic or genotypic association between the disorder and such polymorphism. These findings are in concordance with previous investigation that also showed negative result ${ }^{20}$.

We also tested if there was association between homozygosity and SCZ. There are some reports showing association of homozygosity of other genetic polymorphisms, like the Ser9Gly of the dopamine receptor subtype 3 (DRD3), and $\mathrm{SCZ}^{28,29}$. This type of association may represent a heterozygosity advantage, probably because the presence of two different molecular forms of the neurotransmitter receptor, resulting in an increased ability to respond adaptively to variations in the environment happening either in neural development or adult life ${ }^{30,31}$. However, in our sample there was not found such association as well. This lack of association may occur due to the low frequency of the C516T polymorphism in the population ${ }^{26}$ what requires big samples for the analyses. Other possible limitation of the present investigation is related to the population stratification. Investigations comparing different ethnical populations have shown significant variations in the allelic frequency. Power to detect association may be reduced in ethnic admixture samples ${ }^{32}$. In order to face such a problem we can try to identify the ethnical origin of the sample and try to compound homogenous samples. However in Brazil physical characteristics such as skin pigmentation, hair color and texture, shape of the nose and lips, are poor predictors of genomic ancestry ${ }^{33}$ what difficult the ethnic matching in our case-controls studies. Nevertheless the fact that the present sample is in Hardy-Weinberg equilibrium indicates that our sample may not have important problems of population stratification ${ }^{34}$. Moreover, ethnic matching conducted using genetic markers was performed in part of our sample in a casecontrol study with cocaine dependence and the results showed that despite the ethnic admixture in Brazil the ethnic stratification was not a bias in that case $^{35}$.

Otherwise, the 5-HT2A gene is expressed in various tissues and brain regions, and therefore is likely to be under a complex expression control. There could be different regulatory elements for different cell types, different developmental stages, and even different environments ${ }^{8,9}$ what indicate that its possible role in the pathogenesis of SCZ is not easy to be approached.

In conclusion, the results of this work do not provide evidence of association between SCZ and alleles or genotypes of the C516T polymorphism in the 5HT2A gene with the disorder in the studied sample.

\section{REFERENCES}

1. McGuffin P, Owen MJ, Farmer AE. The genetic basis of schizophrenia. Lancet 1995;346:678-682.

2. Norton N, Williams HJ, Owen MJ. An update on the genetics of schizophrenia. Curr Opin Psychiatry 2006;19:158-164.

3. Gingrich, JA, Hen R. Dissecting the role of the serotonin system in neuropsychiatric disorders using knockout mice. Psychopharmacology 2001;155:1-10.

4. Aghajanian GK, Marek GJ. Serotonin model of schizophrenia: emerging role of glutamate mechanisms. Brain Res Rev 2000;31:302-312.

5. Stahl SM, Wets K. Neurochemistry and neuropharmacology of schizophrenia. London: Elsevier, 1987.

6. Arora R C, Meltzer H Y. Serotonin2 (5HT2) receptor binding in the frontal cortex of schizophrenic patients. J Neural Trans 1991;85:19-29.

7. Joyce J N, Shane A, Lexow N, Winokur A, Cassanova M F, Kleinman J E. Serotonin uptake sites and serotonin receptors are altered in the limbic system of schizophrenics. Neuropsychopharmacology 1993;8:315336.

8. Kapur S, Remington G. Serotonin-dopamine interaction and its relevance to schizophrenia. Am J Psychiatry 1996;153:466-476.

9. Li D, Duan Y, He L. Association study of serotonin 2A receptor (5HT2A) gene with schizophrenia and suicidal behavior using systematic meta-analysis. Biochem Biophys Res Commun 2006;340:1006-1015.

10. Meltzer HY, Li Z, Kaneda Y, Ichikawa J. Serotonin receptors: their key role in drugs to treat schizophrenia. Prog Neuropsychopharmacol Biol Psychiatry 2003;27:1159-1172.

11. Davies MA, Setola V, Strachan RT, et al. Pharmacologic analysis of nonsynonymous coding h5-HT2A SNPs reveals alterations in atypical antipsychotic and agonist efficacies. Pharmacogenomics J 2006;6:42-51.

12. Sparkes RS, Lan N, Klisak I, et al. C. Assignment of a serotonin 5HT-2 receptor gene (HTR2) to human chromosome 13q14-q21 and mouse chromosome 14. Genomics 1991;9:461-465.

13. Waterwort DM, Bassett AS, Brzustowicz LM. Recent advances in the genetics of schizophrenia. Cell Mol Life Sci 2002;59:331-348. 
14. Badner JA, Gershon ES. Meta-analysis of whole-genome linkage scans of bipolar disorder and schizophrenia. Mol Psychiatry 2002;7:405- 411.

15. Chen K, Yang W, Grimsby J, Shih JC. The human 5-HT2 receptor is encoded by a multiple intron-exon gene. Brain Res Molec Brain Res 1992;14:20-26.

16. Harvey L, Reid RE, Ma C, Knight PJ, Pfeifer TA, Grigliatti TA. Human genetic variations in the 5HT2A receptor: a single nucleotide polymorphism identified with altered response to clozapine. Pharmacogenetics 2003;13:107-118.

17. American Psychiatric Association. Diagnostic and statistical manual of mental disorders, $4^{\text {th }}$ edn. Washington, DC: American Psychiatric Association, 1994.

18. Miller SA, Dykes DD, Polesky, HF. A single salting out procedure for extracting DNA from human nucleated cells. Nucleic Acids Res 1988;16:1215.

19. Arranz M, Collier C, Shodi M, et al. Association between clozapine response and allelic variation in 5-HT2A receptor gene. Lancet 1995; 346:281-282.

20. Erdmann J, Shimron-Abarbanell D, Rietschel M, et al. Systematic screening for mutations in the human serotonin-2A (5-HT2A) receptor gene: identification of two naturally occurring receptor variants and association analysis in schizophrenia. Hum Genet 1996;97:614-619.

21. Ott J. Methods of analysis and resources available for genetic trait mapping. J Hered 1999;90:68-70.

22. Ohashi J, Tokunaga K. The power of genome-wide association studies of complex disease genes: statistical limitations of indirect approaches using SNP markers. J Hum Genet 2001;46:478-482.

23. De Luca V, Wong AHC, Muller DJ, Wong GWH, Tyndale RF, Kennedy JL. Evidence of association between smoking and alpha-7 nicotinic receptor subunit gene in schizophrenia patients. Neuropsychopharmacology 2004;29:1522-1526.

24. Cordeiro Q, Vallada H. Lack of association between the G681C polimorphism in the 5-HT1D(beta) autoreceptor gene and schizophrenia. Arq Neuropsiquiatr 2005; 63:380-382.
25. Abdolmaleky HM, Faraone SV, Glatt SJ, Tsuang MT. Meta-analysis of association between the T102C polymorphism of the 5HT2a receptor gene and schizophrenia. Schizophr Res 2004;67:53-62.

26. Gutiérrez B, Bertranpetit J, Collier D, et al. Genetic variation of the 5HT2A receptor gene and bipolar affective disorder. Hum Genet 1997;100:582-584.

27. Meira-Lima I, Shavitt RG, Miguita K, Ikenaga E, Miguel EC, Vallada $\mathrm{H}$. Association analysis of the catechol-o-methyltransferase (COMT), serotonin transporter (5-HTT) and serotonin 2A receptor (5HT2A) gene polymorphisms with obsessive-compulsive disorder. Genes Brain Behav 2004;3:75-79.

28. Crocq MA, Mant R, Asherson P, et al. Association between schizophrenia and homozygosity at the dopamine D3 receptor gene. J Med Genet 1992;29:858-860.

29. Jonsson EG, Flyckt L, Burgert E, et al. Dopamine D3 receptor gene Ser9Gly variant and schizophrenia: association study and meta-analysis. Psychiatr Genet 2003;13:1-12.

30. Cavalli-Sforza LL, Bodmer WF. The genetics of human populations. San Francisco: Freeman, 1971.

31. Spielman RS, Ewens WJ. The TDT and other family-based tests for linkage disequilibrium and association. Am J Hum Genet 1996;59:983-989.

32. McKeigue PM, Carpenter JR, Parra EJ, Shriver MD. Estimation of admixture and detection of linkage in admixed populations by a Bayesian approach: application to African American populations. Ann Hum Genet 2000;64:171-186.

33. Parra FC, Amado RC, Lambertucci JR, Rocha J, Antunes CM, Pena SD. Color and genomic ancestry in Brazilians. Proc Natl Acad Sci USA 2003;100:177-182.

34. Weiss ST, Silverman EK, Palmer LJ. Editorial: case-control association studies in pharmacogenetics. Pharmacogenomics J 2001;1:157-158.

35. Guindalini C, A GSTP1 functional variant associated with cocaine dependence in a Brazilian population. Pharmacogenet Genomics 2005;15: 891-893. 